\title{
Possibilities of composting disposable diapers with municipal solid
}

wastes

Joan Colón ${ }^{1}$, Luz Ruggieri ${ }^{1}$, Aina González ${ }^{2}$, Ignasi Puig ${ }^{2}$ and Antoni Sánchez ${ }^{1, *}$

1) Composting Research Group

Department of Chemical Engineering

Escola d'Enginyeria

Universitat Autònoma de Barcelona

Bellaterra (Cerdanyola, 08193-Barcelona, Spain)

2) Ent, environment and management

C/Sant Joan, 39, 1r

Vilanova i la Geltrú (08800-Barcelona, Spain)

* Corresponding author:

Dr. Antoni Sánchez

Phone: 34-935811019

Fax: $34-935812013$

Email: antoni.sanchez@uab.cat 


\begin{abstract}
The possibilities for the management of disposable diapers in municipal solid wastes have been studied. An in-depth revision of literature about generation, composition and current treatment options for disposable diapers showed that the situation for these wastes is not clearly defined in developed recycling societies. As a promising technology, composting of diapers with source separated organic fraction of municipal solid wastes (OFMSW) was studied at full scale to understand the process performance and the characteristics of the compost obtained when compared to that of composting OFMSW without diapers. The experiments demonstrated that the composting process presented similar trends in terms of evolution of routine parameters (temperature, oxygen content, moisture and organic matter content) and biological activity (measured as respiration index). In relation to the quality of both composts, it can be concluded that both materials were identical in terms of stability, maturity and phytotoxicity and showed no presence of pathogenic microorganisms. However, compost coming from OFMSW with a $3 \%$ of disposable diapers presented a slightly higher level of zinc, which can prevent the use of high amounts of diapers mixed with OFMSW.
\end{abstract}

Keywords: composting, diapers, environmental impact, municipal solid wastes, waste collection. 


\section{Introduction}

The continuous growth in waste generation has become in recent years one of the main environmental problems that modern societies have to face. The increasing rise in society's environmental awareness, along with an increasing difficulty to locate waste facilities such as waste incinerators and landfills (Alçada-Almeida, 2009), has lead Public Administrations to search for alternative waste management solutions, such as composting or recycling.

In particular, in Europe, the recent Directive 2008/98/EC of 19 November 2008 on Waste establishes the following waste hierarchy "a) prevention; b) preparing for reuse; c) recycling; d) other recovery, e.g. energy recovery; and e) disposal" (art. 4). Additionally, Directive 1999/31/EC of 31 April on the landfill of waste sets up significant restrictions on the disposal of biodegradable materials in landfills. According to this Directive, by 2016 the biodegradable municipal waste going to landfills must be reduced to $35 \%$ of the total amount (by weight) of biodegradable municipal waste produced in 1995.

Diaper wastes have a significant proportion of organic materials in their composition, but their final destination in most of the countries is landfill or incineration. In municipalities where high levels of separate waste collection are reached, disposable diapers account for a significant part of the refuse fraction and constitute one of the main difficulties to increase the recycling levels.

As first objective and based on a literature review, this paper describes the main impacts of disposable diapers (section 2) and possible alternative treatments (section 3). Then, as second objective, it experimentally analyses the compostability of disposable 
diapers mixed with the Organic Fraction of Municipal Solid Waste (OFMSW), as a possible alternative treatment to landfill or incineration (section 4). Finally, some conclusions are presented (section 5).

\section{Environmental impacts of disposable diapers}

\section{Composition of disposable diapers}

Composition of disposable diapers is very diverse in materials (Table 1). Additionally, when considering their treatment as waste, in used disposable diapers the presence of solid and liquid excreta also has to be considered. In fact, they represent the two most significant fractions in weight (Table 2). According to Campbell \& McIntosh (1998), the generation of solid and liquid excreta between the age of 0 and 30 months ranges from 0.448 to $0.601 \mathrm{~kg} / \mathrm{day}$ per child (Table 3 ).

The average weight of a clean disposable diaper is $41 \mathrm{~g}$ (EDANA, 2007). For a used disposable diaper the average weight is $212 \mathrm{~g}$, according to experimental data based on the average weight of 610 diapers collected in municipalities of Mancomunitat La Plana (Barcelona, Spain) between 18 and 24 February 2008. Also, the organic part of diapers, considering only cellulose and solid excreta, accounts for $11.4 \%$ of their weight. When urine is also included in the organic part, this increases to $87.4 \%$ of their weight (Table 2).

On the other hand, several aspects have to be considered in relation to the presence of superabsorbent polymers (SAP) in diapers. SAP are polymers with high molecular weight presenting the ability to absorb and retain high quantities of liquid as 
compared to their own weight. In contact with urine, SAP take the form of a gelatinous mixture known as hydrogel. Thus, despite urine is an organic substance, in terms of the visual impact during the composting process, it could be considered an impurity since the high adherence of hydrated SAP to organic materials would make it very difficult to separate it in composting plants. However, according to Cook et al. (1997), the composting process degrades the polymer crosslinkages responsible for the gel formation, urine is released and it can be degraded normally. On the contrary, the SAP molecules are only degraded in a $8 \%$ during a 100 days composting period, although residual polymers continue to degrade (at a rate of $0.007 \%$ per day), which suggests that they will eventually degrade completely. However, given this long degradation time estimated for SAP, it must be pointed out that some harmful effects can appear for human and other environments, as previously reported (Andersen, 2005; Friedman, 2003; Weston et al., 2009), although new materials used for SAP fabrication claim not to be toxic (Demitri et al., 2008; Kosemund et al., 2009). Nevertheless, regarding the composting process, only non-biodegradable molecules should be considered as impurities. Once released, urine initially retained in SAP would be composted with the organic matter present in the mixture.

Generation of disposable diapers. Collection and treatment systems

The generation of waste from disposable diapers has been estimated based on empirical data (sample of 610 used diapers, see above) and bibliographical data on the percentage of children using diapers at different ages (Environment Agency, 2004). The main results are shown in Table 4. 
The estimated generation of waste from disposable diapers in Europe in 2007 (considering births in 2005-2007) was 4278461 tones, which is $1.66 \%$ of total municipal waste generation, and around $3 \%$ of the organic waste fraction present in the municipal solid waste stream. In most European countries, diapers are collected together with the refuse waste and have the same destination. According to Eurostat (2009), in $2006,61 \%$ of municipal solid waste went to landfills or waste incinerators, whereas $39 \%$ had other destinations, such as recycling or composting.

\section{Environmental impact}

The main environmental impacts of disposable diapers occur during the manufacturing process and during their treatment in landfills or incinerators. Impacts occurred during commercialisation, transport and use are considered less important (Aumônier and Collins, 2005). A brief description of the main impacts is presented below:

1) During the manufacturing process:

- The main component of diapers is cellulose pulp (35\% in baby diapers, Table 1), which is mainly obtained from coniferous woods. Associated environmental impacts are deforestation (in case of cellulose pulp obtained from natural forests) or loss of soil quality and loss of biodiversity (in case of cellulose from plantations of fast-growing species). Manufacturing of pulp involves the extensive use of chlorine and alkalis which often ends up in an effluent and results in the synthesis of other potentially harmful substances like dioxins and furans (Lehrburguer et al., 1991). 
- Super Absorbent Polymers account for 33\% of the diapers weight (EDANA, 2007). SAP is formed by sodium polyacrylate crystals. The only references found on the fate of superabsorbent polymers in soil after composting (Cook et al., 1997; Stegmann et al., 1993) have pointed that composting was responsible for degrading crosslinkages between monomers and afterwards degradation of these products should continue in soil leaving no toxic residue. However, as previously mentioned, the long degradation time of SAP and the toxicity of intermediate products of SAP decomposition have promoted the search for new less harmful materials.

- Among all the manufacturing processes involved in the production of the materials that compose diapers, this is the most important in terms of pollution. The production of SAP requires high quantities of water, fuel and natural gas. Additionally, the production of SAP is the main responsible for the emissions of $\mathrm{CO}_{2}, \mathrm{CH}_{4}, \mathrm{SO}_{2}$ and $\mathrm{NO}_{2}$ during the production of disposable diapers (Aumônier and Collins, 2005).

- Other components of the disposable diapers are polypropylene, polystyrene, elastics, adhesives, and plastic bags for packaging, which derive from fossil fuels. Their main impacts are related to the emissions of $\mathrm{CO}_{2}, \mathrm{CH}_{4}, \mathrm{SO}_{2}$ and $\mathrm{NO}_{2}$ (Aumônier and Collins, 2005).

- To produce a ton of disposable baby diapers $1167.82 \mathrm{~kg}$ of materials, 440 litres of water and $723.9 \mathrm{kWh}$ are consumed. $100 \mathrm{~kg}$ of waste are also produced (Aumônier and Collins, 2005).

2) During the commercialisation process and use: The environmental impact associated to the transport, commercialisation and use of disposable diapers is limited to energy 
consumption, and gas emissions related to transportation and infrastructures maintenance.

3) During treatment and disposal:

- In case of landfilling, the main impacts are the use of land, methane emissions and possible leachate to groundwater due to the presence of organic wastes. Disposal of organic waste without a pre-treatment may also entail a risk for human health (WEN, 2003).

- The main impacts of waste incineration are emissions of pollutants to the atmosphere, generation of contaminated wastewater and generation of contaminated ashes (Hester \& Harrison, 1994). The main gases produced due to incineration of diapers are greenhouse gases. However, considering that their composition includes several polymers and organic compounds, their incineration may generate other more pollutant substances, such as $\mathrm{Cl}$ and CO (Riber, 2007).

Table 5 summarises the main environmental impacts related to disposable diapers, according to a life cycle analysis.

\section{Treatment options}

As discussed above, most of the disposable diapers have landfills or waste incinerators as their final destination. However, a number of alternative treatments are being experienced in several countries, as explained below:

- Mechanical-biological treatment (MBT): MBT includes two stages. Initially, in the mechanical treatment, some recyclable materials are separated by means of 
several different methods (manual separation, mechanical sieving, magnets, Foucault separators, etc.). Bulky materials are also manually separated. Afterwards, the remaining materials (mainly biowaste) undergo a biological treatment, which may include aerobic and anaerobic stages or the combination of both. After the biological treatment, biowaste remains stabilised, with a reduced volume and low moisture content. Normally, the compost obtained from MBT has a low quality and it is difficult to commercialise (Slater and Frederickson, 2001). However, these treatments considerably reduce the rejected fraction of municipal solid waste, and the environmental problems associated with this fraction (mainly odours, leachate and reactivity) before its final destination in a landfill. MBT have been used for years all over the world. In Europe, the countries where this system has been applied more widely are Spain, Italy and Germany (Archer et al., 2005).

- Mechanical separation and recycling of the different fractions: the separation of the different recyclable fractions included in diapers (organic matter, plastics, cellulose, SAP) has been experienced in several municipalities in the United States of America, Asia and Europe by the Knowaste company (Knowaste, 2009). Diapers are collected separately and transported to a treatment plant, where they are shredded, washed and their components separated. The resulting materials are: plastics, deactivated SAP, compacted cellulose fibres and composted biowaste. According to Knowaste, this process can divert up to $84 \%$ of the materials from landfills and waste incinerators. The major disadvantage of this process is its high cost.

- Anaerobic digestion: it consists of anaerobic digestion of waste with a high content of organic matter (such as kitchen waste, food packaging, diapers, etc.) 
and the transformation of biogas into electricity. The resulting digested organic matter is then treated by an aerobic process, where it is transformed into compost. Several experiences of this kind are being undertaken in Toronto (Canada) and Brecht (Belgium) (Forkes, 2007; Gellens et al., 1995), where diapers and biowaste are collected together, and subsequently treated in an anaerobic plant.

- Composting: Since the nineties several laboratory experiments were undertaken in relation to composting of disposable diapers and their compounds. Despite the scale of these experiences is often small, and the fact that the majority of them focuses on very specific parts of process, in general they show positive outcomes (Table 6). In addition, since 1998, in the Bapaume region (France), diapers are collected together with biowaste and composted (European Commission, 2000a). Collection is performed on a door-to-door basis, and includes 20000 households. Wastes are carried to the Bapaume composting plant, with a capacity of 7000 tons per year, where they undergo an aerobic composting process and a subsequent maturation stage (Syndicat Mixte de la Région de Bapaume, 2007). High-quality compost is obtained because of the good separation in the households.

Other alternatives to disposable diapers are the use of reusable diapers (which can be made of several fabrics and have to be sanitised after each use) or the use of compostable diapers (made of biodegradable materials).

\section{Composting with the Organic Fraction of Municipal Solid Waste}


To assess the possibility of the composting of used disposable diapers with the OFMSW from source-separation collection systems, a full-scale experiment was carried out. The details of the experience are explained below.

\section{Methodology}

\section{Composting process}

The composting process was carried out in the composting plant of "Mancomunitat la Plana". This plant is located in Malla (Barcelona, Spain) and collects organic wastes from door-to-door collection systems implemented in all the municipalities included in this Mancomunitat (Tona, Balenyà, Taradell, Calldetenes, Viladrau, Folgueroles, Seva and Roda de Ter in the province of Barcelona). The plant is located in a rural area where the nearest neighbourhood is a small industrial area. Particular households are at a distance of approximately $2 \mathrm{~km}$. The present capacity of the plant is close to $100 \mathrm{t} / \mathrm{year}$. Pruning wastes from these municipalities are used as bulking agent.

Two different piles with and without disposable diapers were built. Unfortunately, only one replication could be carried out for both experiments because of the amount required of materials (OFMSW and diapers). It is evident that more research would be necessary to cover possible seasonal variations of both diapers and OFMSW. The steps were followed to build the two piles:

1) Main substrate for composting was the source-separated OFMSW. The waste came from municipalities with a door-to-door separate collection scheme and it was composed of kitchen residues and garden trimmings. The level of impurities of the

OFMSW was lower than 1\% (Agència de Residus de Catalunya, 2009). The main 
characteristics of the used feedstock are shown in Table 7. The disposable used diapers were obtained from the same source separation collection system. They were shredded to $5-10 \mathrm{~cm}$ pieces before composting.

2) OFMSW (16150 kg) was mixed with bulking agent $(7590 \mathrm{~kg})$ consisting of shredded pruning wastes in a volumetric ratio 1:1 to ensure an adequate level of porosity. This mixture was considered the composting experiment without diapers.

3) OFMSW (12720 kg) was mixed with shredded diapers $(555 \mathrm{~kg})$ to obtain $3 \%$ weight percentage of diapers in the OFMSW, which is considered representative of the Spanish use of diapers and the generation of the OFMSW, as previously explained. This mixture was also mixed with the same shredded bulking agent $(5450 \mathrm{~kg})$ in a volumetric ratio 1:1. The resulting mixture was considered the composting experiment with diapers.

Both mixtures were composted in a static forced-aerated covered composting reactor for five weeks (active decomposition stage). During this stage all leachate produced were recirculated into the pile to adjust the moisture content. Afterwards, a non-covered windrow composting system was used for an 18-weeks additional curing process. Both curing piles were built according to the windrow method (Haug, 1993) with a trapezoidal shape of the following approximate dimensions: base: $4 \mathrm{~m}$; height: 2 $\mathrm{m}$; length: 10-15 m. During the curing process, material was turned once a week. No leachate was observed during the entire curing phase. After the curing process, material was sieved to $10 \mathrm{~mm}$ to obtain the final compost. The entire composting experiments lasted from April to October (2008).

To monitor the composting process of both materials during the force-aerated decomposition stage, temperature was daily measured (on-line) in situ at two different depths, $400 \mathrm{~mm}$ and $1000 \mathrm{~mm}$, in four different points. In this stage, temperature values 
are presented as average values of the different monitored points of the pile (Figure 1). Standard deviation of temperature values was within $5-10 \%$. The force-aerated system was designed to provide air to ensure aerobic conditions (oxygen concentration in exhaust air higher than 10\%). During the curing stage, temperature and oxygen were measured only at days $43,53,83$ and 168 . In both stages, temperature was measured using a temperature probe (Pt-100, Desin Instrument, Barcelona, Spain), whereas oxygen concentration was measured using an oxygen sensor (QRAE Plus, Sensotran S.L., Barcelona, Spain) connected to a portable aspiration pump.

Sampling for analysis of compost was taken at days 1, 13, 27, 34, 53, 83 and 168 in both piles. Sub-samples of $5 \mathrm{~kg}$ of the whole material were extracted from four points of each pile. The four sub-samples were mixed manually to obtain a representative sample of each pile. Moisture, organic matter content and respiration index represented in Figures 2 and 3 were determined in an aliquot of at least $1 \mathrm{~kg}$ of this representative sample. The final compost samples characterized in Table 8 were obtained using the same procedure after sieving the material to $10 \mathrm{~mm}$.

\section{Analytical methods}

Dry matter and moisture content, organic matter content, $\mathrm{pH}$, electrical conductivity, total Kjeldahl nitrogen, $\mathrm{C} / \mathrm{N}$ ratio and bulk density were determined in duplicates from the representative sample obtained as previously explained and according to the US Department of Agriculture and the US Composting Council (2001). Dewar® selfheating test was used as a measure of compost maturity (The US Department of Agriculture and the US Composting Council, 2001; Weppen, 2002). Air filled porosity (AFP), also referred in literature as free air space (Agnew and Leonard, 2003), is 
expressed as the ratio of air filled pore volume of the sample to total sample volume. AFP was ex-situ measured with a self-made constant volume air pycnometer according to the description of Oppenheimer et al. (1996). AFP data is presented as an average of a triplicate measure.

Pathogen indicators (Salmonella and E. coli) and heavy metal content (chromium, nickel, lead, copper, zinc, mercury, cadmium and chromium VI) were determined in final compost samples by an external laboratory (Applus Agroambiental S.A., Lleida, Spain).

Phytotoxicity was determined by means of germination index. Cucumis sativus and Phoenix dactylifera seeds were used in this test. Germination index was determined according to standard methodologies (Tiquia et al., 1996; Tiquia \& Tam, 1998). Germination indices were calculated using three replications.

To monitor the activity and stability of the material, respiration index was determined. A static respirometer was built according to the original model described by Iannotti et al. $(1993,1994)$ and following the modifications and recommendations given by Standard Methods (The US Department of Agriculture and The US Composting Council, 2001). The configuration of the respirometer can be found elsewhere (Barrena et al., 2005). Approximately $250 \mathrm{ml}$ of sample were placed in $500 \mathrm{ml}$ Erlenmeyer flasks on a nylon mesh screen that allowed air movement under and through the solid samples. The setup included a water bath to maintain the temperature at $37^{\circ} \mathrm{C}$ during the respirometric test. Prior to the assays, samples were incubated for 24 hours at $37^{\circ} \mathrm{C}$. During all the incubation period samples were aerated with previously humidified air at the sample temperature. The drop of oxygen content in a flask containing a sample was monitored with a dissolved oxygen meter (Lutron 5510, Lutron Co. Ltd., Taiwan) 
connected to a data logger. The rate of respiration of the sample based on organic matter content (OM) was calculated from the slope of oxygen level decrease according to the standard procedures (Iannotti et al., 1993). Results of the respiration index are expressed as mg of $\mathrm{O}_{2}$ consumed per hour and per $\mathrm{g}$ of organic matter and are presented as an average value of three replicates with standard deviation.

\section{Results and discussion}

\section{Composting process performance}

Figure 1 shows the evolution of temperature during the entire process. In both cases (with and without diapers), thermophilic temperatures were reached, which was probably due to the high biodegradability of OFMSW coming from source separated collection systems (Ponsá et al., 2008; Ruggieri et al., 2008). In both piles, it can be concluded that the totality of the material was exposed to temperatures in the thermophilic range and consequently met the international requirements on compost sanitation, which are based on time-temperature conditions (The US Environmental Protection Agency, 1995; European Commission, 2000b). In the case of oxygen content, both piles showed values of oxygen concentration up to $10 \%$ during the entire composting experience (data not shown), which are related to the prevalence of aerobic conditions (Haug, 1993).

Figure 2 shows the evolution of moisture and organic matter content during the composting processes. As observed, both evolutions are very similar. Thus, moisture did not present a clear trend during the decomposition stage; however in none case the variations of moisture values in this stage were important. As the composting system 
was covered, water evaporation was prevented and most of the condensed water vapour returned to the material. Moreover, in order to prevent moisture loss, leachate produced was again recirculated during the decompositional phase. On the contrary, when the material was taken out of the composting reactor for curing in non-covered windrows, water evaporation was considerable and moisture content became limiting. This is especially relevant since the curing process took place during summer conditions, since it has been reported that there is a correlation between composting performance and environmental conditions (McCartney and Eftoda, 2005). In relation to organic matter content, this parameter shows a decrease during the first active decomposition stage to reach a plateau during the curing stage. This trend has been previously observed in other studies related to OFMSW composting and it can be considered as the typical evolution (Ruggieri et al., 2008).

Figure 3 presents the evolution of the respiration index during the entire composting process. Again, the values observed between OFMSW with and without diapers were very similar. As observed in Figure 3, the most important part of biological activity reduction expressed as respiration index occurred during the decomposition stage, when it changed from 5-6 $\mathrm{mg} \mathrm{O}_{2} \mathrm{~g}^{-1} \mathrm{OM} \mathrm{h}^{-1}$ to approximately $2 \mathrm{mg} \mathrm{O}_{2} \mathrm{~g}^{-1} \mathrm{OM}$ $\mathrm{h}^{-1}$. This is an important reduction of activity achieved in a relatively short composting time ( 5 weeks). Afterwards, in the first part of the curing stage, an additional decrease of respiration activity was observed to reach values near $1 \mathrm{mg} \mathrm{O}_{2} \mathrm{~g}^{-1} \mathrm{OM} \mathrm{h}^{-1}$, which are similar to those of stable compost (Barrena et al., 2006a). However, during the last part of the curing stage (from day 80 to day 168), no decrease in biological activity was observed (Figure 3). This fact was probably due to a moisture limitation that prevented the normal development of composting microbial communities. Anyway, this fact 
highlights the suitability of respiration techniques for the monitoring of processes involving biological treatment of organic solid wastes as previously reported (Ponsá et al., 2008; Barrena et al., 2009). On the contrary, other indirect parameters of biological activity such as temperature are not valid to monitor the composting process at fullscale (Figure 1), because of the thermal inertia effect associated to large composting masses that prevents temperature to decrease (Barrena et al., 2006b).

\section{Final compost properties}

Table 8 shows the complete characterization of the final compost obtained with and without diapers. Although some parts of non-degraded pieces of diapers could be visually observed in the material with diapers, they were completely removed during the sieving process. For comparison, in Table 8 the values required for Class A compost (suitable for agronomical purposes) according to the current Spanish legislation (Ministerio de la Presidencia, 2005) are also presented, although it is necessary to comment that at present the requirements for compost in Spanish legislation are being discussed and revised.

The general conclusion to be extracted from Table 8 is that both products are sanitized, stable and of good quality. Also, the differences found between both materials (with and without diapers) are minimal. More specifically:

1) General properties are adequate for OFMSW compost, with a high content of organic matter and a significant amount of nitrogen. $\mathrm{C} / \mathrm{N}$ ratios are around $15-16$, which are also correct for good compost (Bernal et al., 1998). As previously discussed, the property that is far from legislation is moisture content, which is lower than required according to the composting process carried out under limiting conditions of this parameter. Finally, 
the low values observed in the electrical conductivity are related to a low salt content in both composts. This is especially interesting as SAP is believed to be composed of sodium compounds.

2) Stability (respiration index) reached is in accordance to the values presented in Figure 3. Stability is very close to that of what is considered stable compost, although in the last part of the curing stage under moisture limiting conditions, this value remained practically constant. The slight increase observed in the respiration value of the final compost sample in comparison to that of the final sample showed in Figure 3 can be explained according to the concentration of organic matter after the sieving process that implies the removal of bulking agent and non-compostable materials present in the OFMSW (Ruggieri et al., 2008). On the other hand, maturity grade (III) corroborates the results obtained with the respiration index and with some previous studies (Barrena et al., 2006c).

3) Compost presents no phytotoxicity according to the values of germination indices obtained for both Cucumis sativus and Phoenix dactylifera. Typically, compost with values of germination index over $80 \%$ is assumed to be non phytotoxic (Tiquia et al., 1996; Tiquia \& Tam, 1998).

4) Sanitation has been highly effective and none of the pathogenic microorganisms used as indicators have been detected. It is evident that the temperature reached and the number of turnings during the curing stage has a positive effect on sanitation.

5) In relation to heavy metals content, it is clear that the levels detected for both materials are very low. Both composts are classified into Class A compost, which can be used for agriculture purposes. The sole exception would be the zinc content in the compost with diapers, which is equal to the limit value for Class A. As zinc is 
commonly used in pomades for skin baby care (Runeman, 2008; Visscher, 2009) and as supplement for baby powder milks (Ikem et al., 2002), it can be hypothesized that the origin of this zinc is diapers, although this fact should be confirmed in further studies. For instance, there are other hypotheses to explain the relatively higher content of zinc in the compost with diapers, since this metal is commonly used and can be present in shredding machines used for diapers, metal containers used for diapers accumulation, etc. Moreover, it has been reported that bulking agent can also add a baseline content of zinc that could affect both composts (Smith, 2009; Kim et al., 2008).

\section{Conclusions}

From the literature reviewed in this study, it can be concluded that disposable diapers are an important part of the overall stream of municipal solid wastes. Although diapers have received little attention in research studies and their main destination is landfill or incineration, several alternative management options have been explored in literature showing promising results in terms of recovery improvement and recycling.

The co-composting process of the source-separated organic fraction of municipal solid waste with disposable diapers at full-scale has shown no technical problems in the biological process in terms of stability, phytotoxicity and sanitation of the resulting compost. The sole exception for compost quality when diapers were included was a slightly higher concentration of zinc in compost. Another uncertainty derives from the unknown behaviour of superabsorbent polymers in soil. These two aspects, jointly with the research for new less toxic materials that may be used as superabsorbents, should be the objectives of further research on this field. 


\section{Acknowledgments}

The authors wish to thank the financial support provided by the Spanish Ministerio de Ciencia y Tecnología (Project CTM2006-00315), as well as the support provided by Agència de Residus de Catalunya (Generalitat de Catalunya) and Mancomunitat Intermunicipal Voluntària La Plana. Joan Colón thanks Universitat Autònoma de Barcelona for the award of a pre-doctoral scholarship. 


\section{References}

Agència de Residus de Catalunya (2009). Characterizations of OFMSW (in Spanish) (http://www.arc.cat/ca/municipals/recollidaselectiva/rmordinaris/materiaorganic a/caracform.html), accessed December 2009.

Agnew, J.M., Leonard, J.J. (2003). The Physical Properties of Compost. Compost Science and Utilization 11, 238-264.

Alçada-Almeida, L., Coutinho-Rodrigues, J., Current, J. (2009). A multiobjective modelling approach to locating incinerators. Socio-Economic Planning Sciences 43, 111-120.

Andersen, F.A. (2005). Amended final report on the safety assessment of polyacrylamide and acrylamide residues in cosmetics. International Journal of Toxicology 24, 21-50.

Archer, E., Klein, A., Whiting, K. (2005). Mechanical-Biological-Treatment: A Guide for Decision Markers. Processes, Policies and Markets. Juniper Consultancy Services Ltd.

Aumônier, S., Collins, M. (2005). Life Cycle Assessment of Disposable and Reusable Nappies in the UK. Environment Agency. (http://publications.environmentagency.gov.uk/pdf/SCHO0505BJCW-e-e.pdf), accessed December 2009.

Barrena, R., Vázquez, F., Gordillo, M.A., Gea, M.T., Sánchez, A. (2005). Respirometric Assays at Fixed and Process Temperatures to Monitor Composting Process. Bioresource Technology 96, 1153-1159.

Barrena, R., Vázquez, F., Sánchez, A. (2006a). The Use of Respiration Indices in the Composting Process: A Review. Waste Management and Research 24, 37-47. 
Barrena, R., Cánovas, C., Sánchez, A. (2006b). Prediction of temperature and thermal inertia effect in the maturation stage and stockpiling of a large composting mass. Waste Management 26, 953-959.

Barrena, R., Pagans, E., Faltys, G., Sánchez, A. (2006c). Effect of inoculation dosing on the composting of source-selected organic fraction of municipal solid wastes. Journal of Chemical Technology and Biotechnology 81, 420-425.

Barrena, R., d’Imporzano, G., Ponsá, S., Gea, T., Artola, A., Vázquez, F., Sánchez, A., Adani, F. (2009). In search of a reliable technique for the determination of the biological stability of the organic matter in the mechanical-biological treated waste. Journal of Hazardous Materials 162, 1065-1072.

Bernal, M.P., Paredes, C., Sánchez-Monedero, M.A., Cegarra, J. (1998). Maturity and stability parameters of composts prepared with a wide range of organic wastes. Bioresource Technology 63, 91-99.

Campbell, A., MacIntosh, N. (1998). Forfar and Arneil's Textbook of Pediatrics, 5th edition. Churchil Livingstone.

Cook, B.D., Bloom, P.R., Halbach, T.R. (1997). Fate of a Polyacrylate Polymer during Composting of Simulated Municipal Solid Waste. Journal of Environmental Quality 26, 618-625.

Demitri, C., Del Sole, R., Scalera, F., Sannino, A., Vasapollo, G., Maffezzoli, A., Ambrosio, L., Nicolais, L. (2008). Novel superabsorbent cellulose-based hydrogels crosslinked with citric acid. Journal of Applied Polymer Science 110, 2453-2460. 
EDANA (2007). Sustainability Report 2007-2008. Absorbent Hygiene Products. (www.edana.org/content/default.asp?PageID=75\&DocID=2132), accessed December 2009.

Environment Agency (2004). Time to change? An Environment Agency study of parental habits in the use of disposable and reusable nappies. Environment Agency, London.

Espinosa, R.M., Delfín-Alcalá, I., Turpin, S., Contreras, J.L. (2003). Kinetic Study of Batch Biodegradation of Diapers. International Journal of Chemical Reactor Engineering 1, note S6.

European Commission (2000a). Success stories on composting. (http://ec.europa.eu/environment/waste/publications/pdf/compost_en.pdf), accessed December 2009.

European Commission (2000b). Working document on sludge, 3rd draft. (http://ec.europa.eu/environment/waste/sludge/pdf/sludge_en.pdf), accessed December 2009.

Eurostat (2009). Environmental Data Centre on Waste. (http://ec.europa.eu/eurostat/waste), accessed December 2009.

Forkes, J. (2007). Nitrogen balance for the urban food metabolism of Toronto, Canada. Resources, Conservation and Recycling 52, 74-94.

Friedman, M. (2003). Chemistry, biochemistry, and safety of acrylamide. A review. Journal of Agricultural and Food Chemistry 51, 4504-4526.

Gellens, V., Boelens, J., Verstraete, W. (1995). Source separation, selective collection and in reactor digestions biowaste. Antonie van Leeuwenhoek 67, 79-89. 
Gerba, C., Huber, M.S., Naranjo, J., Rose, J.B., Bradford, S. (1995). Occurrence of enteric pathogens in composted domestic solid waste containing disposable diapers. Waste Management and Research 13, 315-324.

Haug, R.T. (1993). The practical handbook of compost engineering. Lewis Publishers, Boca Raton.

Hester, R.E., Harrison, R.M. (1994). Waste Incineration and the Environment. Issues in environmental science and technology. Royal Society of Chemistry.

Iannotti, D.A., Pang, T., Toth, B.L., Elwel, D.L., Keener, H.M., Hoitink, H.A.J. (1993). A quantitative respirometric method for monitoring compost stability. Compost Science and Utilization 1, 52-65.

Iannotti, D.A., Grebus, M.E., Toth, B.L., Elwell, D.L., Madden, L.V., Hoitink, H.A.J. (1994). Oxygen respirometry to assess stability and maturity of composted municipal solid waste. Journal of Environmental Quality 23, 1177-1183.

Ikem, A., Nwankwoala, A., Odueyungbo, S., Nyavor, K., Egiebor, N. (2002). Levels of 26 elements in infant formula from USA, UK, and Nigeria by microwave digestion and ICP-OES. Food Chemistry 77, 439-447.

Kim, J-D., Park, J-S., In, B-H., Kim, D., Namkoong, W. (2008). Evaluation of pilotscale in-vessel composting for food waste treatment. Journal of Hazardous Materials 154, 272-277.

$\begin{array}{lllll}\text { Knowaste } & \text { (2009). } & \text { The } & \text { recycling }\end{array}$ (http://www.knowaste.com/recycle_process.php), accessed December 2009.

Kosemund, K., Schlatter, H., Ochsenhirt, J.L., Krause, E.L., Marsman, D.S., Erasala, G.N. (2009). Safety evaluation of superabsorbent baby dialers. Regulatory Toxicology and Pharmacology 53, 81-89. 
Lehrburguer, C., Mullen, J., Jones, C.V. (1991). Diapers: environmental impacts and lifecycle analysis. The National Association of Diaper Services (NADS). Philadelphia, Pennsylvania.

MacLeod, J.A., Sanderson, J.B., Douglas, B., Henry, R. (1998). Use of municipal compost in potato rotation. National Agricultural Compost Trials-Results of Year III. Composting Council of Canada. (www.compost.org/cccPotatoRotationCompost.htm), accessed December 2009.

McCartney, D., Eftoda, G. (2005). Windrow Composting of Municipal Biosolids in a cold climate. Journal of Environmental Engineering and Science 4, 341-352.

Ministerio de la Presidencia (2005). Real Decreto 824/2005, de 8 de julio, sobre $\begin{array}{llll}\text { productos } & \text { fertilizantes } & \text { (in } & \text { Spanish). }\end{array}$ (http://www.boe.es/boe/dias/2005/07/19/pdfs/A25592-25669.pdf), accessed December 2009.

Oppenheimer, J., Martin, J., Walker, L. (1996). Measurements of air-filled porosity in unsaturated organic matrices using a pycnometer. Bioresource Technology 59, 241-247.

Ponsá, S., Gea, T., Alerm, L., Cerezo, J., Sánchez, A. (2008). Comparison of aerobic and anaerobic stability indices through a MSW biological treatment process. Waste Management 28, 2735-2742.

Riber, C. (2007). Evaluation of Waste Specific Environmental Impacts from Incineration. PhD Thesis, Institute of Environment and Resources, Technical University of Denmark. (http://www2.er.dtu.dk/publications/fulltext/2007/MR2007-170.pdf), accessed December 2009. 
Ruggieri, L., Gea, T., Mompeó, M., Sayara, T., Sánchez, A. (2008). Performance of different systems for the composting of the source-selected organic fraction of municipal solid waste. Biosystems Engineering 101, 78-86.

Runeman, B. (2008). Skin interaction with absorbent hygiene products. Clinics in Dermatology 26, 45-51.

Slater, R.A., Frederickson, J. (2001). Composting municipal waste in UK: some lessons from Europe. Resources, Conservation and Recycling 32, 359-374.

Smith, S.R. (2009). A critical review of the bioavailability and impacts of heavy metals in municipal solid waste composts compared to sewage sludge. Environment International 35, 142-156.

Stegmann, R., Lotter, S., King, L., Hopping, W.D. (1993). Fate of an absorbent gelling material for hygiene paper products in landfill and composting. Waste Management and Research 11, 155-170.

Syndicat Mixte de la Région de Bapaume (SMRB) (2007). Rapport annuel sur le prix et la qualité du service public d'élimination des déchets (in French). (www.sivomdutricastin.fr/dl.php?file=38), accessed December 2009.

The US Department of Agriculture and TheUS Composting Council (2001). Test methods for the examination of composting and compost. Edaphos International, Houston.

Tiquia, M.S., Tam, N.F.Y., Hodgkiss, I.J. (1996). Effects of composting on phytotoxicity of spent pig-manure sawdust litter. Environmental Pollution 93, 249-256. 
Tiquia, M.S., Tam, N.F.Y. (1998). Elimination of phytotoxicity during co-composting of spent pig-manure sawdust litter and pig sludge. Bioresource Technology 65, 43-49.

US Environmental Protection Agency (1995). A Guide to the Biosolids Risk Assessments for the EPA Part 503 Rule. (http://www.epa.gov/owm/mtb/biosolids/503rule), accessed December 2009.

Visscher, M.O. (2009). Update on the Use of Topical Agents in Neonates. Newborn and Infant Nursing Reviews 9, 31-47.

Weppen, P. (2002). Determining compost maturity: evaluation of analytical properties. Compost Science and Utilization 10, 6-15.

Weston, D.P., Lentz, R.D., Cahn, M.D., Ogle, R.S., Rothert, A.K., Lydy, M.J. (2009). Toxicity of Anionic Polyacrylamide Formulations when Used for Erosion Control in Agriculture. Journal of Environmental Quality 38, 238-247.

Women's Environmental Network (WEN) (2003). Disposable nappies: a case study in waste prevention. Women's Environmental Network.. (http://www.wen.org.uk/nappies/reports/Disposable_nappies_casestudy.pdf), accessed December 2009. 


\section{Tables}

Table 1: Average baby diaper composition in 2006. Source: EDANA (2007).

\begin{tabular}{lc}
\hline Material & Weight percentage $(\%)$ \\
\hline Cellulose pulp & 35 \\
Superabsorbent polymer (SAP) & 33 \\
Polypropylene & 17 \\
Polystyrene & 6 \\
Adhesives & 4 \\
Other & 4 \\
Elastics & 1 \\
\hline
\end{tabular}


Table 2: Average composition of used disposable baby diapers. Source: own elaboration based on EDANA (2007), Campbell and MacIntosh (1998) and empirical data from 610 baby diapers produced in Mancomunitat La Plana (Barcelona, Spain).

\begin{tabular}{lcc}
\hline Material & $\begin{array}{c}\text { Weight } \\
(\mathrm{g})\end{array}$ & $\begin{array}{c}\text { Weight percentage } \\
(\%)\end{array}$ \\
\hline $\begin{array}{l}\text { Non organic materials } \\
\text { polypropylene, polystyrene, adhesives, }\end{array}$ & 0.027 & 12.74 \\
elastics, other) & & \\
Cellulose pulp & 0.014 & 6.60 \\
Faeces & 0.010 & 4.72 \\
Urine & 0.161 & 75.94 \\
Total organic without urine & 0.024 & 11.37 \\
Total organic with urine & 0.185 & 87.43 \\
\hline
\end{tabular}


Table 3: Average excreta production per child. Source: Campbell and McIntosh (1998).

\begin{tabular}{lccc}
\hline Age (months) & $\begin{array}{c}\text { Urine mass rate } \\
(\mathrm{kg} / \mathrm{day})\end{array}$ & $\begin{array}{c}\text { Faeces mass rate } \\
(\mathrm{kg} / \mathrm{day})\end{array}$ & $\begin{array}{c}\text { Total mass rate } \\
(\mathrm{kg} / \text { day })\end{array}$ \\
\hline $0-3$ & 0.42 & 0.028 & 0.448 \\
$3-6$ & 0.42 & 0.031 & 0.451 \\
$6-12$ & 0.47 & 0.031 & 0.501 \\
$12-24$ & 0.58 & 0.031 & 0.611 \\
$24-30$ & 0.57 & 0.031 & 0.601 \\
\hline
\end{tabular}


Table 4: Average diaper production per child. Source: own elaboration based on Environment Agency (2004) and empirical data from 610 baby diapers produced in Mancomunitat La Plana (Barcelona, Spain).

\begin{tabular}{lcccc}
\hline Age (months) & $\begin{array}{c}\text { Children wearing } \\
\text { diapers } \\
(\%)\end{array}$ & $\begin{array}{c}\text { Number of } \\
\text { changes per }\end{array}$ & $\begin{array}{c}\text { Average diaper } \\
\text { weight } \\
(\mathrm{kg})\end{array}$ & $\begin{array}{c}\text { Diapers weight } \\
\text { per child } \\
(\mathrm{kg} / \text { year })\end{array}$ \\
\hline Up to 6 & 100 & 7 & & 536.55 \\
6 to 12 & 95.7 & 7 & & 513.48 \\
12 to 18 & 82.8 & 5 & & 317.33 \\
18 to 24 & 45.6 & 5 & & 174.76 \\
24 to 30 & 17.6 & 5 & & 67.45 \\
30 to 36 & 4.8 & 5 & & 18.40 \\
\hline
\end{tabular}


Table 5: Environmental impacts derived from the use of disposable diapers during the first 2.5 years of a child's life considering an average number of 4.16 changes per day. Source: Aumônier and Collins (2005).

\begin{tabular}{|c|c|c|c|}
\hline Impact category & Unit & $\begin{array}{c}\text { Mixed } \\
\text { Scenario* }\end{array}$ & $\begin{array}{c}\text { Geigy } \\
\text { Scenario* }\end{array}$ \\
\hline Abiotic resource depletion & $\mathrm{Kg} \mathrm{Sb} \mathrm{eq}$ & 4.82 & 4.85 \\
\hline Global warming & $\mathrm{Kg} \mathrm{CO}_{2}$ eq & 626.0 & 602.0 \\
\hline Ozone layer depletion & $\mathrm{Kg} \mathrm{CFC}^{-11}$ eq & 0.000261 & 0.000202 \\
\hline Photochemical oxidation & $\mathrm{Kg} \mathrm{C}_{2} \mathrm{H}_{2}$ eq & 0.174 & 0.163 \\
\hline Acidification & $\mathrm{Kg} \mathrm{SO}_{2}$ eq & 3.78 & 3.79 \\
\hline Eutrophication & $\mathrm{Kg} \mathrm{PO}_{4}{ }^{3-}$ eq & 0.338 & 0.337 \\
\hline Human toxicity** & $K g$ 1,4-DB eq & 49.4 & 48.9 \\
\hline Fresh water aquatic ecotoxicity & $K g 1,4-D B e q$ & 7.01 & 5.98 \\
\hline Terrestrial. ecotoxicity & Kg 1,4-DB eq & 1.92 & 1.9 \\
\hline
\end{tabular}

* The original source analyses two scenarios in relation to excreta produced by children between 0 and 24 months, according to different references.

** Italics indicate less developed impact methodologies according to the original source. 
Table 6: Summary of different scientific reports in relation to biodegradation of disposable diapers.

\begin{tabular}{|c|c|c|c|}
\hline Authors & Year & Objective & Conclusions \\
\hline Stegmann et al. & 1993 & $\begin{array}{l}\text { To study the fate and effects } \\
\text { of hydrated SAP in landfills } \\
\text { and during aerobic } \\
\text { composting }\end{array}$ & $\begin{array}{l}\text { SAP caused no adverse effects on the } \\
\text { degradation of diapers. Most of the } \\
\text { material remained associated with the } \\
\text { diaper pad and surrounding waste, } \\
\text { whereas a small part (less than } 6.4 \% \text { ) } \\
\text { was biodegraded. }\end{array}$ \\
\hline Gerba et al. & 1995 & $\begin{array}{l}\text { To study the presence of } \\
\text { enteric pathogenic viruses } \\
\text { and protozoan parasites in } \\
\text { municipal waste }\end{array}$ & $\begin{array}{l}\text { No viruses or intact nucleic acid are } \\
\text { detected after a composting process of } \\
175 \text { days. }\end{array}$ \\
\hline Cook et al. & 1997 & $\begin{array}{l}\text { To study the composting } \\
\text { process of SAP together } \\
\text { with municipal waste }\end{array}$ & $\begin{array}{l}\text { During the composting process only } \\
\text { low-molecular-weight polymers were } \\
\text { degraded (around } 8 \% \text { of total } \\
\text { polymers), which are those that have } \\
\text { demonstrated a greater mobility } \\
\text { potential in soils. For the rest of } \\
\text { polymers the structural integrity of the } \\
\text { polymer chains was maintained during } \\
\text { the composting process. }\end{array}$ \\
\hline MacLeod et al. & 1998 & $\begin{array}{l}\text { To analyse the effects of } \\
\text { composting with and without } \\
\text { diapers in barley and potato } \\
\text { crops. }\end{array}$ & $\begin{array}{l}\text { The observed rise in the yields of } \\
\text { forage is similar using both types of } \\
\text { compost. There is a lack of studies } \\
\text { regarding absorption of heavy metals } \\
\text { by potatoes. }\end{array}$ \\
\hline Espinosa et al. & 2003 & $\begin{array}{l}\text { To study the } \\
\text { biodegradability of diapers }\end{array}$ & $\begin{array}{l}\text { The biodegradation of diapers takes } \\
\text { place in aerobic conditions at } \\
\text { temperatures above } 60^{\circ} \mathrm{C} \text { and } \mathrm{pH} \text { lower } \\
\text { than 5.8. In these conditions, organic } \\
\text { materials decrease by } 56 \% \text { and } \\
\text { nitrogen concentration increases by } \\
48 \% \text {. }\end{array}$ \\
\hline
\end{tabular}


Table 7: Properties of the used Organic Fraction of Municipal Solid Wastes (once mixed with bulking agent in a volumetric ratio 1:1).

\begin{tabular}{lc}
\hline Parameter & Value \\
\hline Dry matter content $(\%)$ & 42.3 \\
Organic matter content (\%, dry basis) & 74.0 \\
$\mathrm{pH}$ & 4.80 \\
Electrical conductivity $(\mathrm{mS} / \mathrm{cm})$ & 4.50 \\
Nitrogen $(\mathrm{Kjeldahl})(\%$, dry basis $)$ & 1.70 \\
$\mathrm{C} / \mathrm{N}$ ratio & 24 \\
Respiration index $\left(\mathrm{mg} \mathrm{O}_{2} \mathrm{~g}^{-1} \mathrm{OM} \mathrm{h}^{-1}\right)$ & 5.43 \\
Bulk density $(\mathrm{kg} / \mathrm{l})$ & 0.44 \\
Air filled porosity $(\%)$ & 48.2 \\
Impurities $(\%)$ & $<1$ \\
\hline
\end{tabular}


Table 8: Properties of the final compost obtained with and without diapers. Spanish legislation corresponds to Class A compost according to Ministerio de la Presidencia (2005).

\begin{tabular}{|c|c|c|c|}
\hline Parameter & $\begin{array}{c}\text { Compost } \\
\text { without diapers }\end{array}$ & $\begin{array}{c}\text { Compost } \\
\text { with diapers }\end{array}$ & $\begin{array}{c}\text { Spanish } \\
\text { Legislation }\end{array}$ \\
\hline Dry matter content $(\%)$ & 74.3 & 76.0 & $60-70$ \\
\hline Organic matter content (\%, dry basis) & 63.1 & 56.0 & $>35$ \\
\hline $\mathrm{pH}$ & 9.05 & 8.05 & No value \\
\hline Electrical conductivity $(\mathrm{mS} / \mathrm{cm})$ & 2.01 & 1.98 & No value \\
\hline Nitrogen (Kjeldahl) (\%, dry basis) & 2.33 & 1.94 & No value \\
\hline $\mathrm{C} / \mathrm{N}$ ratio & 15 & 16 & $<20$ \\
\hline Respiration index $\left(\mathrm{mg} \mathrm{O}_{2} \mathrm{~g}^{-1} \mathrm{OM} \mathrm{h}^{-1}\right)$ & 1.40 & 1.57 & No value \\
\hline Bulk density (kg/l) & 0.36 & 0.40 & No value \\
\hline Air filled porosity (\%) & 61 & 57 & No value \\
\hline E. $\operatorname{coli}(\mathrm{CFU} / \mathrm{g})$ & $<10$ (Absence) & 20 (Absence) & $<1000$ \\
\hline Salmonella (Presence/Absence in $25 \mathrm{~g}$ ) & Absence & Absence & Absence \\
\hline Germination index Cucumis sativus (\%) & 94 & 133 & No value \\
\hline Germination index Phoenix dactylifera $(\%)$ & 98 & 91 & No value \\
\hline Chromium (mg/kg, dry matter basis) & 9 & 14 & 70 \\
\hline Nickel (mg/kg, dry matter basis) & 9 & 14 & 25 \\
\hline Lead (mg/kg, dry matter basis) & 28 & 26 & 45 \\
\hline Copper (mg/kg, dry matter basis) & 44 & 41 & 70 \\
\hline Zinc (mg/kg, dry matter basis) & 156 & 200 & 200 \\
\hline Mercury (mg/kg, dry matter basis) & 0.06 & 0.09 & 0.4 \\
\hline Cadmium (mg/kg, dry matter basis) & 0.3 & 0.3 & 0.7 \\
\hline Chromium VI (mg/kg, dry matter basis) & $<0.50$ & $<0.50$ & 0 \\
\hline
\end{tabular}




\section{Figure legends}

Figure 1: Evolution of temperature during the composting process of the Organic Fraction of Municipal Solid Wastes, with and without diapers. Vertical dotted line separates decomposition (forced aeration process) from maturation (turned pile process) stages.

Figure 2: Evolution of moisture and organic matter contents during the composting process of the Organic Fraction of Municipal Solid Wastes, with and without diapers. Vertical dotted line separates decomposition (forced aeration process) from maturation (turned pile process) stages.

Figure 3: Evolution of respiration index during the composting process of the Organic Fraction of Municipal Solid Wastes, with and without diapers (standard deviation for respiration index triplicates is represented for each point). Vertical dotted line separates decomposition (forced aeration process) from maturation (turned pile process) stages. 
Figure 1.-

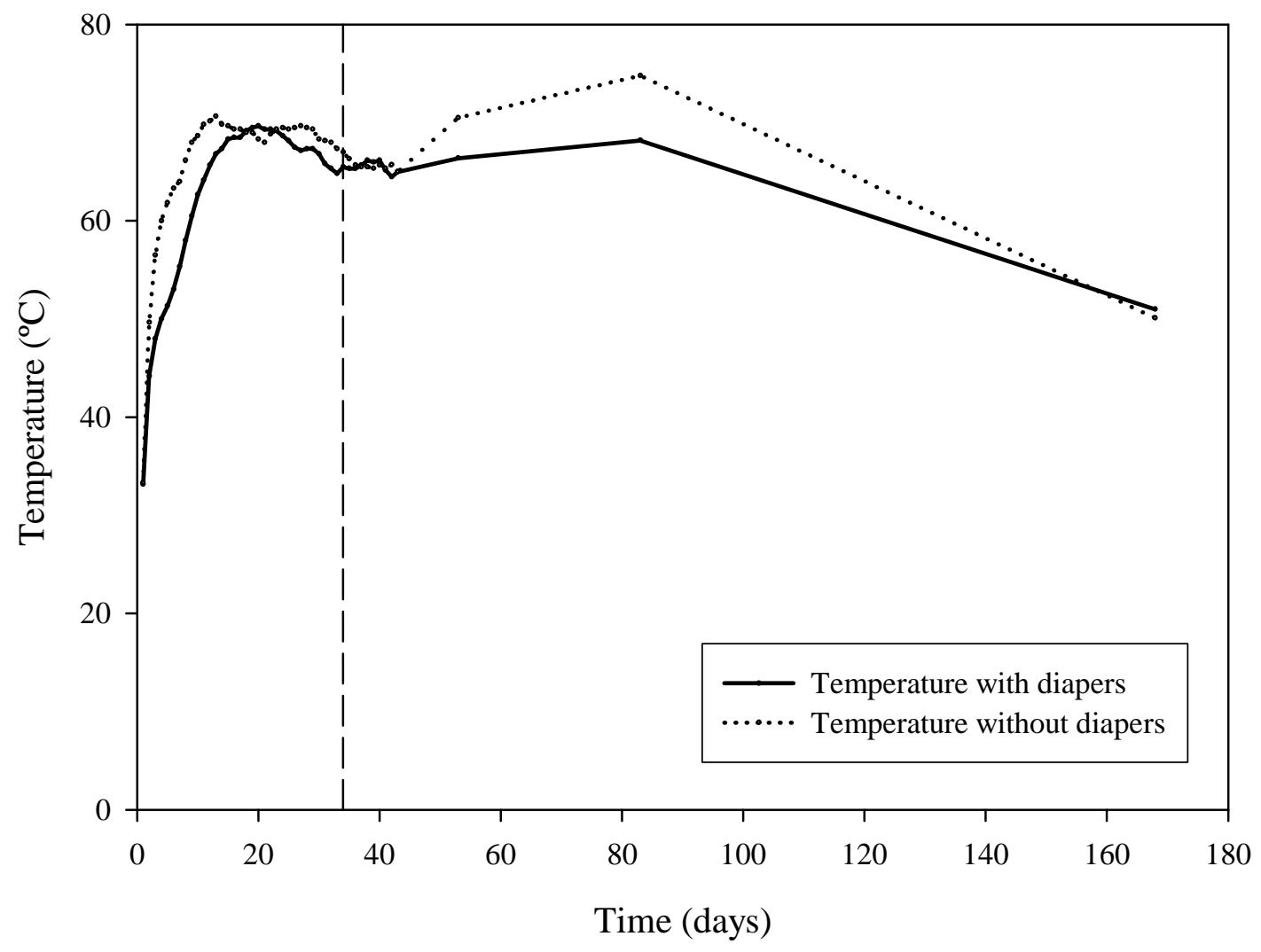


Figure 2.-

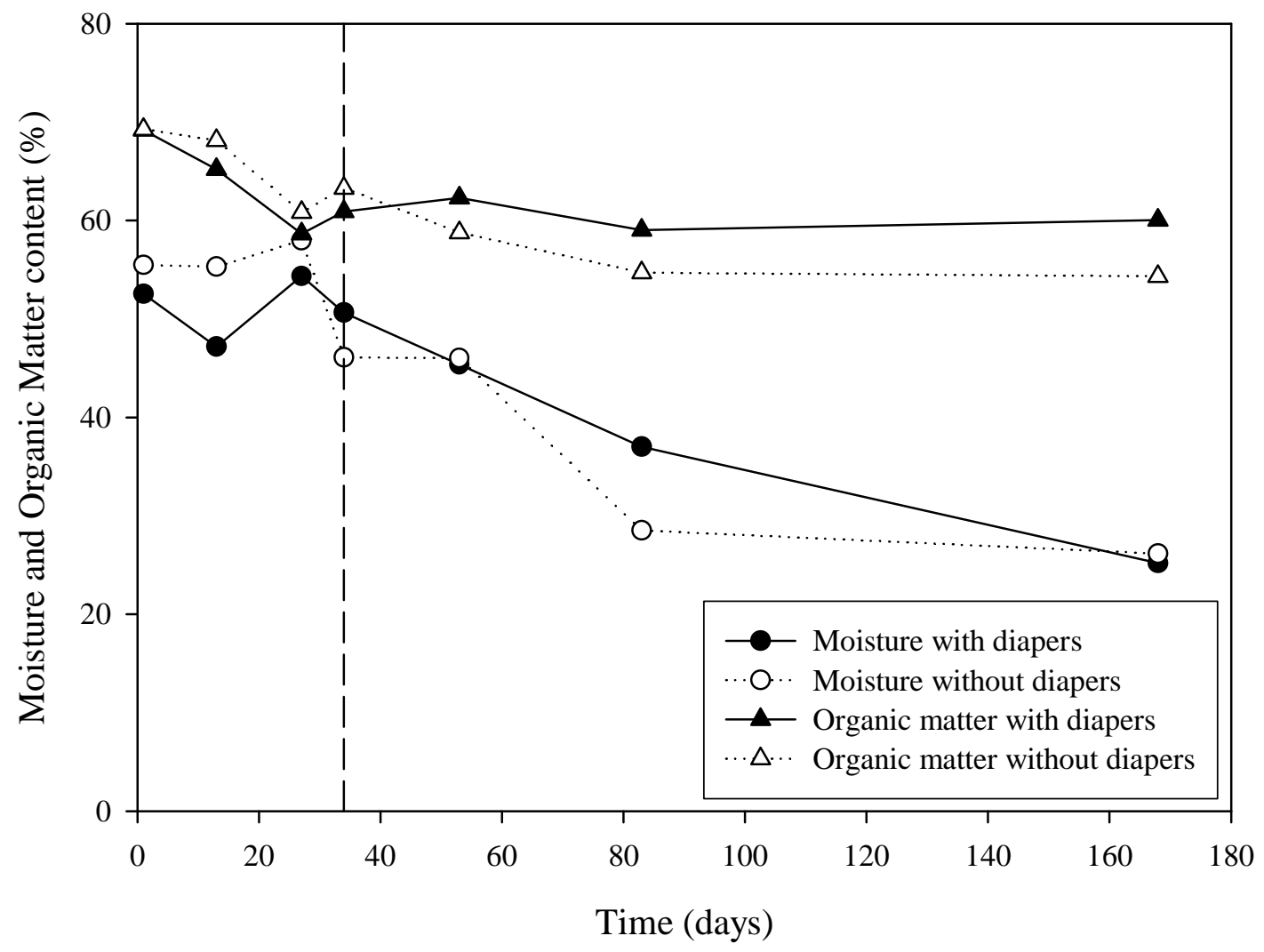


Figure 3.-

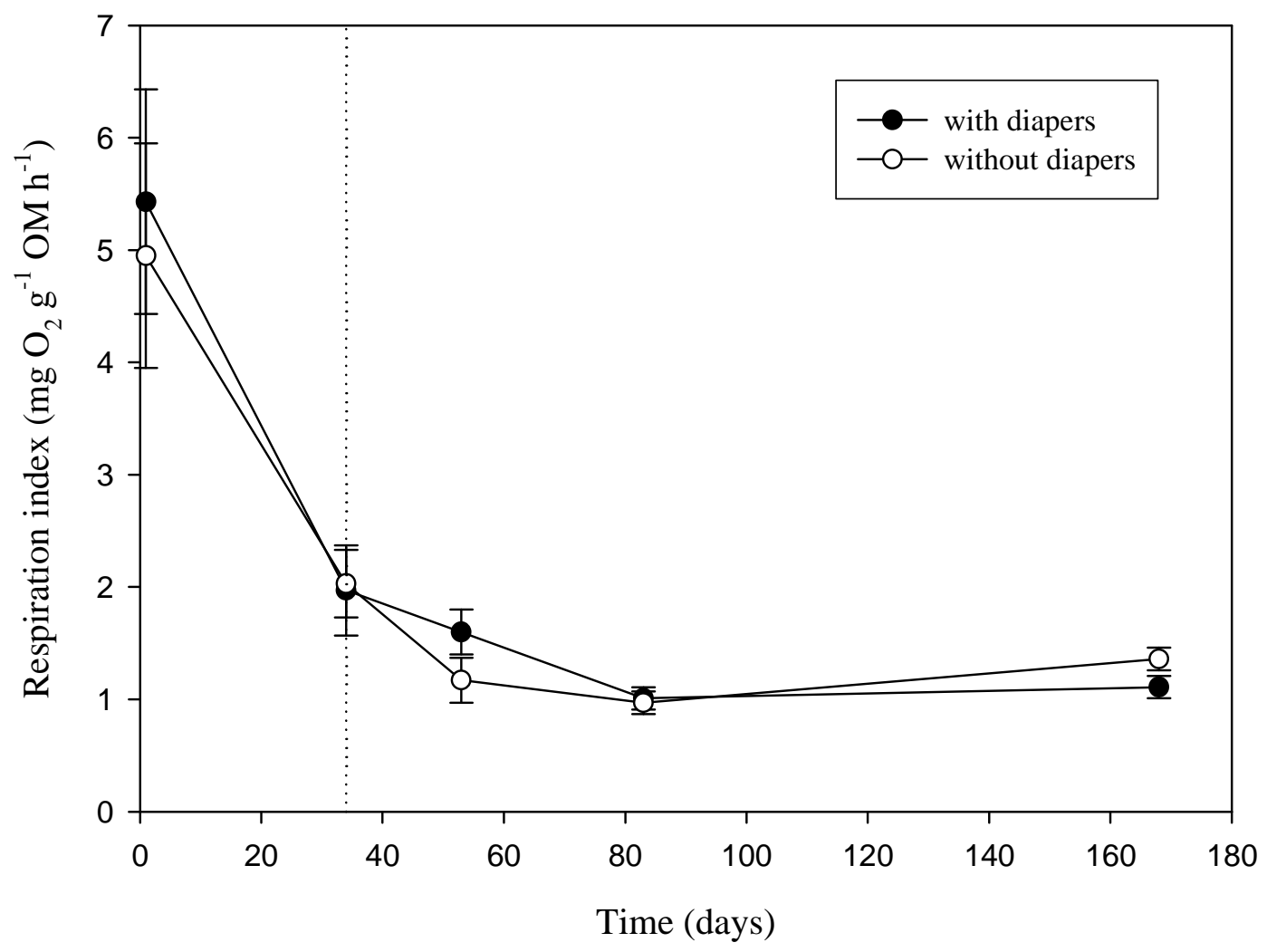

